\title{
MILITARY SERVICE CONSPICUOUS
}

\author{
By REP. A. N. HARBERT
}

Having disposed of his interest in the Vinton Eagle Oct. 3, 1860, and being an applicant for an appointment to a civil office under the new administration, Tom Drummond had gone to the inauguration of President Lincoln as a guest of the Iowa delegation. Party spirit at that time was thoroughly aroused, and he watched the contending forces with intense interest. In the meantime, he returned home, and the day the word reached Vinton that Sumter had fallen, he forwarded his resignation as state senator to Governor Kirkwood, and returned by stage to Washington.

The army was being increased, and through the influence of Senator Harlan, who was a particular friend, Drummond was commissioned a second lieutenant in the Fifth (old Second) U. S. cavalry, April 26, 1861. He joined the regiment at Washington on the $22 \mathrm{~d}$ of May, participated in the capture of Arlington, Virginia, and served at that place until the 13th of June, when, having been promoted a first lieutenant to date from May 30, 1861, he was assigned to the command of a company. He served at Arlington in the field, and in the defenses of Washington to the 20th of October, participated in the Manassas campaign, was engaged in the skirmish at Blackburn's Ford, and the battle of Bull Run, where he was distinguished by daring intrepidity. In retreat of the army at Bull Run, he was in command of his company, which formed the rear guard, the post of honor, where he displayed dauntless courage, repulsing the Black Horse cavalry, which was pursuing and frequently charging upon them. The following graphic account of that engagement, in an extract from a letter written by him to Judge Douglas, was published in the Vinton Eagle, August 1, 1861:

I got into camp yesterday. I was in the fight of the 18th at Bull Run and the first shot fired by the enemy, (a rifled cannon shot) wounded the $2 d$ sergeant of my company $(G)$, and wounded one other man and horse. I had a private wounded afterwards, 328 
by a minnie ball, while we were covering the retreat of the 12th N. Y. regiment, which broke and ran.

On Sunday morning, at 2 a.m., I was in the saddle and never out of it except for a moment, until 9 a.m. of the $22 \mathrm{~d}$. We marched at 3 a.m. for our second fight, which proved to be the hardest battle ever fought on this continent. We were defeated-routed -utterly routed and broken up. I was detailed at the beginning of the action to remain with my company (I recommended it) near General McDowell, and had a full view of the whole battle, which lasted eight hours. Shot, shell and minnie balls rained around us, but the regulars stood like rocks. I lost four horses, but thank God, no men.

When the retreat became a rout, I joined the remaining cavalry to protect the rear. After going two miles, I was detailed to the extreme rear, behind two of Arnold's guns. We were in sight of Centerville, when the enemy opened on our battery guns, and Colonel Heintzelman ordered them to be abandoned. They were spiked and left, while Fieintzelman under escort of my company took to the left, avoiding the road. I got into our old camp near Centerville, two hours after the other six companies of cavalry, and in two hours more was again in the saddle in full retreat through Fairfax.

I did my duty, obeyed every order, was the last in retreat, (as I was at the fight of the 18th) and yet was unhurt, notwithstanding balls flew all around me. While acting as an aid to carry orders for the general I kept thinking of God and Old Benton, trying to pray, and at the same time, kept the credit of Iowa good. It was a good joke on the praying I expect, but about the nerve and gallantry others can speak.

He was appointed lieutenant colonel of the Fourth Iowa cavalry December 24, 1861, and transferred to that command in January of the next year. It was one of the requirements of the war department that the lieutenant colonelcy was to be given to some officer of the regular army, who should be an instructor in tactics and discipline. He was a very strict disciplinarian and noted for carrying it to extremes at times. He became at once a conspicuous figure in the regiment. Wm. Forse Scott, historian of the regiment, says of him:

He was young and handsome, highly intelligent, with a very distinct personal and military pride, and impetuous to the point of recklessness. He set about disciplining and training the regiment with an imperious energy that startled the men, and gave them 
for the first time the idea that a soldier is a man who obeys another man's orders. He would hear no excuse for failure or neglect, he had no patience with dullness or slowness, and his comments upon the shortcoming of an officer were as prompt and distinct, and as forcible and impolite in language, as upon those of a private.

Some of the men he punished for offenses which they considered trivial. To them, in their greenness, the taking of a bit of rest when on guard, some disorder on dress parade, leaving a horse once ungroomed, might be contrary to strict army regulations, but was not criminal, and the volunteers were not hireling soldiers, but free and independent American citizens. This spirit, the necessary result of American institutions, was hard to control in the army. Indeed it was never wholly controlled, though it was slowly subordinated to higher consideration, through the good sense which hard experience taught the volunteer. Gradually they learned the value, the necessity, of discipline.

But in their camp the men found comfort in knowing that their officers suffered too; for Colonel Drummond kept the officers in a "school," where daily and without mercy he instructed and harassed them, characterizing in no diplomatic phrases any lack of capacity that he found. He became quickly the one powerful man in the camp, the most hated, feared, and admired.

With such men as composed the average volunteer regiment at the beginning of the war it hardly would be possible for such an officer to succeed. Colonel Drummond tried hard, but he had little support or encouragement from either officers or men, and he met constantly as much difficulty and obstruction as could be put in his way.

He went into the field with the regiment, serving in Arkansas and Tennessee, and was engaged with the enemy upon several occasions, until June 3, 1862, when he resigned his volunteer commission and was transferred back to the Fifth cavalry in the east.

He participated in the Virginia peninsular and Maryland campaigns, and was engaged in the skirmishes near Sycamore church and White Oak swamp, with the regiment as a part of the rear guard of the Army of the Potomac during the evacuation of the peninsula, the battles of South Mountain and Antietam, the skirmish near Shepherdstown, and the engagement near Halltown. 
He was promoted a captain July 17, 1862, and assumed the command of his company on the 25 th of September, and participated in the action near Piedmont, the skirmish near Union and Upperville, the actions at Makham's station and Amissville, and the skirmish at Barbee's crossroads. He served during the winter of 1862-63 near Falmouth, Virginia, and was employed on provost-guard duty near that place during the spring of 1863, and participated in Maj. Gen. George Stoneman's raid towards Richmond, April and May, and was engaged in the combat near Brandy station and the skirmish at Shannon hill. He served as provost-marshal of the cavalry corps of the Army of the Potomac from the 8th of June to the $3 \mathrm{~d}$ of August, 1863, when he rejoined the regiment at Winchester, Virginia, and commanded it until the 1st of February, when he availed himself of a leave of absence.

He rejoined on the 31st of March, 1865, and participated in the closing Richmond campaign, and commanded the regiment in the action between Dinwiddie courthouse and Five Forks on the 31st of March, and in the battle of Five Forks on the 1st of April, 1865, where he was mortally wounded.

When he was taken to the rear he desired the chaplain of the Second Massachusetts cavalry to pray with him. The chaplain said, "It is sweet and glorious to die for one's country," and Drummond repeated it in the original, "dulce et decorum est pro patria mori." The chaplain then asked, "Are you willing to give up all for your country?" He replied, "Yes, it is worth all." He said he was thankful that he had been permitted to live to see the success of our cause certain. He lived from 11:00 a.m., until 8:00 a.m., of the following day.

He talked freely of his spiritual condition, and died like a soldier, content with his fate and thinking of his family. His conduct was noble and heroic to the last, and he rejoiced to know that he died as a soldier and patriot. Just as a final victory had nearly been achieved, one that was speedily to restore peace, another of Iowa's noble sons was sacrificed upon the altar of his country. 
A committee at Wheeling received the remains on Wednesday evening, and conveyed them to the senate chamber of the state capitol, where they lay in state until Friday morning. The funeral services were held at the Fourth street Methodist Episcopal church. A procession was then formed, embracing the military escort, officers of the army, the governor and state officers, and citizens to follow the remains to Bridgeport, where another military escort, detailed by the adjutant general of the state, received them and proceeded to St. Clairsville. With the usual military honors, he was laid to rest by the side of his mother, which was his request.

Drummond was strongly impressed with the belief that he would be killed at Five Forks, and appeared at the head of the regiment wearing his best uniform so that, as he expressed himself, he would present a respectable appearance in death. He was a brilliant young officer, and although somewhat restive under the restraints of military discipline, was held in high estimation for his ability, judgment and courage. He was the last officer of the regiment who fell in battle during the rebellion against the United States.

It had already come about that Captain Drummond was spoken of in the Fourth Iowa cavalry with great respect and admiration and with sincere interest in his career; for the volunteers had in the meantime learned something of soldiering. The G.A.R. post of St. Clairsville, West Virginia, was named in honor of his memory, and the tablet now stationed in that institution which he helped to create and establish, likewise does him reverence. 
Copyright of Annals of Iowa is the property of State of Iowa, by \& through the State Historical Society of Iowa and its content may not be copied or emailed to multiple sites or posted to a listserv without the copyright holder's express written permission. However, users may print, download, or email articles for individual use. 